\title{
Epidemiology and Pathology of Strawberry Anthracnose: A North American Perspective
}

\author{
Barbara J. Smith ${ }^{1}$ \\ U.S. Department of Agriculture, Agricultural Research Service, Thad Cochran Southern Horticultural Laboratory, \\ Small Fruit Research Unit, P.O. Box 287, Poplarville, MS 39470
}

Additional index words. Colletotrichum acutatum, C. fragariae, C. gloeosporioides, Fragaria $\times a n a n a s s a$, disease control, fungicides

\begin{abstract}
Three Colletotrichum species-Colletotrichum acutatum J.H. Simmonds (teleomorph Glomerella acutata J.C. Guerber \& J.C. Correll), Colletotrichum fragariae A.N. Brooks, and Colletotrichum gloeosporioides (Penz.) Penz. \& Sacc. in Penz. [teleomorph Glomerella cingulata (Stoneman) Spauld. \& H. Schrenk]—are major pathogens of strawberry (Fragaria $\times$ ananassa). Strawberry anthracnose crown rot has been a destructive disease in commercial strawberry fields in the southeastern United States since the 1930s. The causal fungus, $C$. fragariae, may infect all aboveground plant parts; however, the disease is most severe when the fungus infects the crown, causing crown rot, wilt, and death. Colletotrichum gloeosporioides was responsible for an epidemic of anthracnose crown rot in strawberry nurseries in Arkansas and North Carolina in the late 1970s. The anthracnose fruit rot pathogen, $C$. acutatum, was first reported in 1986 on strawberry in the United States. Since the 1980 s, increased losses due to anthracnose fruit and crown rots in the United States may be related to changes in cultivars and to widespread use of annual plasticulture production rather than the matted-row production system. Anthracnose investigations in the United States have concentrated on its epidemiology and differences among the three causal Colletotrichum spp. in their cultural, morphological, and molecular characteristics; their infection processes; and their pathogenicity. Results from these studies have resulted in a better understanding of the diseases and have led to better disease control. Strawberries grown in soils with high nitrogen levels are more susceptible to anthracnose than are those grown in soils with lower nitrogen levels or those amended with calcium nitrate. Anthracnose is spread more rapidly in fields that have overhead irrigation and plastic mulch than in fields where drip irrigation and straw mulch are used. Fungicide efficacy has been determined in in-vitro, greenhouse, and field studies, and pathogen resistance to some fungicides has been detected. Anthracnose-resistant cultivars are a major objective of most strawberry breeding programs in the southern United States.
\end{abstract}

Colletotrichum species cause serious diseases of many fruit and vegetable crops worldwide, and three species, C. fragariae, C. acutatum, and C. gloeosporioides, cause anthracnose diseases of strawberry (Smith and Black, 1990). Since the 1930s, anthracnose crown rot caused by $C$. fragariae and C. gloeosporioides has been a destructive disease in strawberry nurseries and fruitproduction fields in the southeastern United States (Brooks, 1931). In 1986, the presence of the anthracnose fruit rot pathogen, C. acutatum, was first reported on strawberry in the United States (Smith and Black, 1986). Increased losses due to anthracnose fruit and crown rots in the United States since the 1980s may be related to the shift from matted-row culture to the annual plasticulture production system, as well as to changes in cultivars. Anthracnose diseases are increasing in importance and resulting in major economic losses to strawberry growers worldwide. The objective of this report is to summarize anthracnose related research from the United States (excluding research from California and Florida) so that we can better understand these diseases and their control.

\section{ANTHRACNOSE PATHOGENS}

Colletotrichum fragariae, C. acutatum, and C. gloeosporioides (Howard et al.,

\footnotetext{
Mention of trade names or commercial products in this article is solely for the purpose of providing specific information and does not imply recommendation or endorsement by the U.S. Department of Agriculture.

${ }^{1}$ To whom correspondence should be addressed; e-mail Barbara.Smith@ars.usda.gov
}

1992; Smith, 1998a, 1988b, 1988c) cause anthracnose diseases of strawberries. $C$. fragariae was assumed to be the causal agent of strawberry anthracnose in the United States until 1986 when Smith and Black (1986) reported the presence of $C$. acutatum on strawberry in the United States. This fungus had previously been reported to cause anthracnose fruit rot of strawberry in Queensland, Australia (Simmonds, 1965); however, it had probably been present in the United States for some time under the name of Gloeosporium spp. (Maas, 1984). Colletotrichum gloeosporioides causes anthracnose crown rot, petiole lesions, and leaf spots indistinguishable from those caused by C. fragariae.

In a series of comparative studies of these three major causal agents of strawberry anthracnose, Smith and Black (1990) examined the cultural characteristics, conidia, appressoria, and setae of 24 Colletotrichum isolates. Colletotrichum fragariae isolates developed beige to olive to dark gray colonies, did not form the ascigerous state in culture, and their conidia were typically cylindrical with one end sharply tapered and the other end rounded. Colletotrichum gloeosporioides isolates were very similar except they formed the Glomerella cingulata ascigerous state in culture and their conidia usually were rounded on both ends. Isolates of both $C$. fragariae and C. gloeosporioides produced dark black setae, visible with a hand lens, in acervuli in culture and on petiole, stolon, and fruit lesions. Colletotrichum acutatum isolates produced fusiform conidia tapered on both ends; developed white, pink, orange, rose, or beige colonies; and did not form setae or the ascigerous state in culture. The growth rate of $C$. acutatum in culture was slower than the other two species at all temperatures tested with the greatest difference being at $32{ }^{\circ} \mathrm{C}$.

Colletotrichum fragariae, the "original" anthracnose fungus, was first identified in Florida in 1931 (Brooks, 1931). It spread throughout the southeastern United States and was responsible for crown rot and death of many plants in strawberry nurseries in the 1970s (Horn et al., 1972). It has a narrow host range, infecting only strawberry and a few weed hosts, and is rarely found outside the southeastern United States. Colletotrichum fragariae generally causes more severe petiole and crown symptoms than C. acutatum, and $C$. fragariae is considered by some to be a host-specific or con-specific form of C. gloeosporioides (Howard, 1983; Howard et al., 1992; Sutton, 1992).

In the late 1970s, C. gloeosporioides was identified as the causal agent on plants obtained from Arkansas and North Carolina nurseries that died from a crown rot identical to that caused by C. fragariae (Howard et al., 1992). It has a wide host and geographic range, causing diseases of many plant hosts worldwide.

The greatest economic losses due to anthracnose on strawberry are from fruit rot caused by $C$. acutatum, which also infects many other fruit and vegetable crops, including apples, tomatoes, peppers, peaches, blueberries, blackberries, and grapes (Bernstein et al., 1995; Howard et al., 1992; Smith, 2002). The presence of the pathogen has been reported on strawberries in almost all areas of the world where they are grown. Crown infections of strawberry plants by $C$. acutatum often result in stunted plants rather than 
plant death. Infected plants usually do not thrive after transplantation and produce few berries at harvest.

Historically, C. acutatum has been considered to be the anthracnose fruit-rotting pathogen, and C. fragariae and C. gloeosporioides have been associated with petiole and stolon lesions and crown rot; however, all three species may cause similar symptoms and may be found to occur on the same plant (Howard et al., 1992). Identification of these pathogens should be based on classical taxonomic characteristics or molecular techniques, not symptoms.

Results of several studies suggest that C. acutatum may have evolved into a subgroup that is highly virulent and host-specific to strawberries. In one of these studies (Denoyes-Rothan et al., 2002), 95 isolates of Colletotrichum, including 81 isolates of C. acutatum (62 from strawberry) and 14 isolates of $C$. gloeosporioides (13 from strawberry), were characterized by various molecular methods and pathogenicity tests. Results based on random amplified polymorphic DNA (RAPD) polymorphism and internal transcribed spacer 2 (ITS2) sequence data provided genetic evidence of two subgroups within $C$. acutatum. The first subgroup, characterized as CA-clonal, included only isolates from strawberry and exhibited identical RAPD patterns and nearly identical ITS2 sequence analyses. A larger genetic group, CA-variable, included isolates from various hosts and exhibited variable RAPD patterns and divergent ITS2 sequence analysis. On the bases of these molecular data, Denoyes-Rothan et al. (2002) proposed that the CA-clonal subgroup contained closely related, highly virulent $C$. acutatum isolates that may have developed host specialization to strawberry. Isolates of Colletotrichum spp. have been disseminated worldwide, probably through international plant exchanges, as their genetic polymorphism and geographical origins are not correlated (Denoyes-Rothan et al., 2002; Sreenivasaprasad and Talhinhas, 2005).

\section{ANTHRACNOSE DISEASE SYMPTOMS}

Anthracnose crown rot (Smith, 1998a), caused by either C. fragariae or C. gloeosporioides, is first apparent by the wilting of the youngest leaves in the hottest part of the day. The young wilted leaves may appear to recover and become turgid in the evenings; however, most will wilt and die after a few days. Shortly after plants wilt, a red discoloration appears within the crown tissue, and the causal pathogen may be isolated from discolored tissue. After the plants have been dead for several days, the crown tissue will turn dark brown to black, and then Colletotrichum spp. is difficult to isolate. Colletotrichum acutatum also may cause crown death; however, typically a single side crown is infected rather than the entire crown, and infected plants are stunted but do not die. Each of the three Colletotrichum spp. may cause petiole and stolon lesions which are dark brown or black and sunken and often girdle the petiole or stolon. Pink masses of conidia are usually visible near the center of each lesion. All three species also cause leaf spots (Howard et al., 1992; Maas and Palm, 1997; Smith, 1998c). Black leaf spot, typically caused by $C$. fragariae and $C$. gloeosporioides, is characterized by gray or light black spots, usually not necrotic, peppered across the top surface of the strawberry leaflets. C. acutatum more typically causes irregular leaf spot, the primary symptom of which is the appearance of necrotic black lesions at the tip of the leaflets. All three Colletotrichum spp. also cause flower blights and fruit rots (Smith, 1998b). Fully open flowers are much more susceptible than closed buds (Smith, 1993). Infected green fruit are often hard and brown and mummify rather than ripen. Anthracnose lesions on ripe fruit are firm, slightly sunken and covered with pink spore masses. Colletotrichum acutatum also causes root lesions.

\section{ANTHRACNOSE INFECTION PROCESS AND PATHOGEN DISPERSAL}

Curry et al. (2002) studied the infection process of strawberry petioles and stolons by C. acutatum and C. fragariae using light and electron microscopy. Both fungal species invaded the host tissue in a similar manner; however, $C$. fragariae invaded the plants more rapidly than did $C$. acutatum. Both species penetrated the cuticle via an appressorium, and their hyphae grew within the cuticle and cell walls of epidermal, subepidermal, and subtending cells. They began invasion with a brief biotrophic phase, in which they invaded living cells, before entering an extended necrotrophic phase, in which they proliferated among dead cells. Acervuli formed once the cortical tissue had been moderately disrupted and developed as a stroma just beneath the outer periclinal epidermal walls. Acervuli erupted through the cuticle and released conidia. Invasion of the vascular tissue typically occurred after acervuli matured but remained minimal.

The time from infection of the strawberry by Colletotrichum spp. to first sporulation (the latent period) is an important factor in the speed at which anthracnose may spread within a field. The latent period depends on the temperature and ranges from 2-3 d at $25^{\circ} \mathrm{C}$ to $6-17 \mathrm{~d}$ at $5{ }^{\circ} \mathrm{C}$ (King et al., 1997). At 5 and $10^{\circ} \mathrm{C}$, the latent period was shorter for C. acutatum than for C. gloeosporioides and $C$. fragariae; however, at higher temperatures the latent period for all species was similar. Appressoria and secondary conidia produced by $C$. acutatum on symptomless foliage may be a significant source of inoculum for fruit infections (Leandro et al., 2001) and may also contribute to the availability of inoculum throughout the growing season (Leandro et al., 2003a). Conidial germination, appressorial production, and secondary conidiation are all favored by longer periods of wetness than the $4 \mathrm{~h}$ required for secondary conidia to form. $\mathrm{Col}$ letotrichum acutatum survived up to 8 weeks on leaves in greenhouse studies (Leandro et al., 2003a) and up to 5 weeks on fabric (Norman and Strandberg, 1997). More conidia formed on leaves when exposed to flower extracts than when exposed to leaf extracts or water (Leandro et al., 2003b), suggesting that C. acutatum inoculum levels on strawberry foliage may increase during flowering.

Rain splash is the primary means by which Colletotrichum spp. conidia are spread from plant to plant in the field. Madden and Boudreau (1997) found that anthracnose fruit rot incidence generally declined as plant density increased and concluded that plant density reduced the amount of rain that penetrated the plant canopy, thus reducing the amount of splash. Most fruit infection occurred in a $25-\mathrm{cm}$ radius of the source of the inoculum, an infected fruit (Madden and Wilson, 1997). Ntahimpera et al. (1999) studied splash dispersal of the conidia of the three Colletotrichum spp. and found that conidia of $C$. fragariae dispersed over the shortest distance and those of $C$. acutatum dispersed over the longest distance. This was probably due to the greater amount of spores produced on infected fruit by $C$. acutatum. Colletotrichum acutatum conidia may survive in soil and plant debris under dry conditions for up to 12 months, but conidia and sclerotia die rapidly under moist conditions, i.e., soil moisture $\geq 12 \%$ (Norman and Strandberg, 1997).

\section{ANTHRACNOSE CULTURAL CONTROL MEASURES}

Because the primary source of infection in most fruiting fields appeared to be infected transplants, strawberry growers in the southeastern United States were advised after the anthracnose crown rot epidemics in the 1980s to obtain their transplants from nurseries in the northern United States, Canada, or California that were believed to be outside the range of $C$. fragariae. More recently, $C$. acutatum has been found in some of the nurseries in these areas. McInnes et al. (1992a) demonstrated that anthracnose-free transplants can be produced in the southeastern United States by locating nurseries in areas where strawberries are not grown commercially. Disease-free transplants remain the primary control of anthracnose crown rot and fruit rot.

Because Colletotrichum spp. may infect many other hosts, primary infection in strawberry fields sometimes is assumed to come from these other hosts growing near the strawberry field. To test the hypothesis that Colletotrichum spp. may move from other fruit or vegetable hosts to strawberry, 37 Colletotrichum isolates, representing nine species collected from 12 hosts, were wound-inoculated onto the leaves and stems of strawberry, blueberry, blackberry, muscadine grape, tomato, and pepper (Smith, 2002). Colletotrichum fragariae isolates 
were the most aggressive and caused lesions at an average of $38 \%$ of inoculation sites on all hosts except pepper. Percentages of infection for the other species were $25 \%$ Colletotrichum capsici, $18 \%$ C. gloeosporioides, $15 \%$ C. acutatum, $11 \%$ C. destructivum, $9 \% C$. truncatum, $8 \%$ C. coccodes, $6 \%$ C. higginsianun, and $5 \%$ C. orbiculare. Strawberry was the most susceptible host with $58 \%$ of petiole and $14 \%$ of leaf inoculations of all isolates resulting in lesion development. Pepper was the most resistant host with no symptom development on leaves or stems following inoculation with any isolate. These results suggest that primary anthracnose infections in strawberry fields are most often from infected strawberry transplants and only rarely from other diseased fruit or vegetable hosts.

Anthracnose spreads within a field by splashing water, and living mulches (such as wheat, rye, or rye grass) in row middles have been shown to reduce disease spread within a field. Sublethal doses of grassspecific herbicides such as sethoxydim, may be used to prevent excessive growth of rye grass (Gupton, 2000). Organic mulches, such as wheat straw or pine needles, will also reduce splash and result in lower incidence of anthracnose compared with rows mulched with plastic (Madden, 1992; Smith and Spiers, 1986). Anthracnose is less severe when water is supplied to plants using drip irrigation rather than overhead irrigation (Madden, 1992; Smith and Spiers, 1986).

Anthracnose crown rot was observed to be less severe in commercial fields when strawberries were grown on soils with low nitrogen fertility (Howard, et al., 1992). In greenhouse studies, Smith $(1987,1989)$ determined that strawberries grown in soils with high levels of nitrogen, especially from ammonium sources, are more susceptible to anthracnose than plants grown in soils with lower nitrogen levels or those with high levels of calcium nitrate. Anthracnose fruit rot caused by C. acutatum was less severe on fruit from greenhouse-grown plants receiving drench or foliar applications of calcium sulfate than on fruit from plants receiving water, calcium chloride, or calcium nitrate treatments. Fruit from plants receiving foliar applications of $\mathrm{CaCl}_{2}$ developed less fruit rot than that from plants receiving soil applications of $\mathrm{CaCl}_{2}$ (Smith and Gupton, 1993).

The primary means to reduce the buildup of anthracnose fruit rot in the field is to harvest fruit frequently and remove all rotten fruit from the field. Following severe infections early in the fruiting season, all infected fruit should be stripped from the plants and removed from the field. Infected areas of a field should be harvested last in the day, or workers should wash up and change to clean clothes when they must enter un-infected areas of the field after they have harvested areas where fruit rot is present.

\section{IN-VITRO FUNGICIDE STUDIES}

Until highly resistant cultivars are available, growers must rely on chemical applica- tions and cultural practices to reduce losses due to anthracnose. Failure of fungicides to control anthracnose epidemics may be due to the development of fungicide resistance in the Colletotrichum spp. population. For example, benomyl was shown to effectively reduce the incidence of anthracnose crown rot (Horn et al., 1972; Howard, 1971) and was used intensively by strawberry growers for years to control anthracnose and other diseases. However, the anthracnose pathogens, C. acutatum and C. fragariae, developed resistance to it and other bendimidazole fungicides (LaMondia, 1995; McInnes et al., 1992a; Smith and Black, 1992, 1993), and benomyl was no longer effective for anthracnose control in strawberry fields. In-vitro trials have been used to screen fungicides for their ability to control anthracnose (LaMondia, 1993; McInnes et al., 1992b; Smith and Black, 1992). Smith and Black (1993) reported that all $16 C$. acutatum, 14 out of $18 C$. fragariae, and both C. gloeosporioides isolates they tested in vitro were resistant to benomyl and that all benomyl-resistant isolates were also resistant to carbendazim, which is in the same class of fungicides as benomyl. In a greenhouse study, plants treated with propiconazole had lower disease severity ratings than did plants treated with captafol or benomyl (Smith and Black, 1991). However, the propiconazoletreated plants were shorter with dark green leaves that appeared thicker than the leaves of untreated plants.

\section{FIELD FUNGICIDE TRIALS}

Sixteen different fungicide treatments were evaluated in five fungicide studies conducted at Hammond, LA, and Poplarville, MS, during the 2002, 2003, and 2005 fruiting seasons (Wedge et al., 2007). Treatments were applied at 7- to 10-d intervals to three strawberry cultivars. The most frequent fruit rots at harvest were anthracnose fruit rot (caused by Colletotrichum spp.), stem end rot (caused by Gnomonia comari P. Karst), and Botrytis gray mold (caused by Botrytis cinerea Pers.:Fr.). Compared with the untreated control treatment, less anthracnose fruit rot occurred on berries from the pyraclostrobin + boscalid, cyprodinil + fludioxonil, azoxystrobin, pyraclostrobin, captan + fenhexamid, and captan treatments.

\section{USDA-ARS ANTHRACNOSE BREEDING PROGRAM}

In the early 1980 s, when anthracnose became a major disease of strawberries in the southeastern United States, a breeding program to develop anthracnose-resistant cultivars adapted to the strawberry-growing areas in the southeastern United States was instituted by the USDA-ARS at the Small Fruit Research Station, Poplarville, MS, and the Fruit Laboratory, Beltsville, MD, with the collaboration of state experiment stations in Florida, Louisiana, and North Carolina (Galletta et al., 1997; Smith and Spiers,
1982). From 1976 to 1995 , over 160,000 progeny from 448 crosses made at Beltsville, MD, primarily by G.J. Galletta, were screened for anthracnose resistance in the greenhouse at Poplarville, MS. Initially, parent lines were eastern cultivars and advanced selections from the breeding program at Beltsville. As the program progressed, resistant selections from the anthracnose program were crossed with commercial cultivars to improve the horticultural characteristics of the progeny. Seed from the crosses made at Beltsville were germinated at Poplarville, and resultant seedlings were inoculated with a conidial suspension of $C$. fragariae, incubated in a dew chamber for $48 \mathrm{~h}$, moved to a warm greenhouse, and rated for anthracnose severity 30 $\mathrm{d}$ after inoculation. Resistant seedlings were evaluated in the field in Florida, Louisiana, Mississippi, Maryland, and North Carolina; selections were made on the bases of yield, fruit quality, plant habit, and resistance to leaf scorch [caused by Diplocarpon earlianum (Ellis \& Everh.) F.A. Wolf], leaf spot [caused by Mycosphaerella fragariae (Tul.) Lindau], powdery mildew [caused by Sphaerotheca macularis (Wallr.:Fr.) Jacz f. sp. fragariae Peries], and two-spotted spider mites (Tetranychus urticae Koch).

Fifteen hundred fifteen (1515) anthracnose-resistant selections were made from the seedlings field-tested in Mississippi. Four of these anthracnose-resistant strawberry clones were released as breeding lines (Galletta et al., 1993) and have been used as the source of anthracnose resistance in several breeding programs. Smith et al. (1998) released the cultivar Pelican, which is highly resistant to both anthracnose crown rot caused by C. fragariae and anthracnose fruit rot caused by $C$. acutatum. 'Pelican' is also resistant to five races of red stele caused by Phytophthora fragariae. Evaluation of strawberry seedlings and advanced breeding lines from state and private breeding programs is an ongoing project. The USDA anthracnose-resistance screening procedure has effectively identified resistant genotypes in seedling progenies from the North Carolina State University breeding program, with $>32,000$ resistant strawberry seedlings identified between 1998 and 1999 (Ballington et al., 2002).

Smith and Black (1987) found that resistance to $C$. fragariae was influenced by environmental conditions after inoculation and that plants incubated at a high temperature $\left(35^{\circ} \mathrm{C}\right)$ for $48 \mathrm{~h}$ in a dew chamber (relative humidity near 100\%) had higher disease severity ratings when compared with plants incubated at 25 or $30{ }^{\circ} \mathrm{C}$. Plants maintained in a greenhouse at $32{ }^{\circ} \mathrm{C}$ after dew chamber incubation developed more severe symptoms than did those held in a greenhouse at $25{ }^{\circ} \mathrm{C}$. Two- to 4-week-old strawberry seedlings (age after transplanting at the first true-leaf stage) were more susceptible to $C$. fragariae than 14- to 18 -weekold seedlings when spray inoculated with a conidial suspension (Smith et al., 1990).

Tissue culture-induced (somaclonal) variation is another strategy being pursued 
for generating disease-resistant genotypes. Hammerschlag et al. (2006) screened shoots regenerated from leaf explants of six commercially important cultivars for resistance to a virulent isolate of C. acutatum. Somaclones with higher levels of anthracnose resistance were identified for all the cultivars, and the greatest increases in disease resistance were observed for somaclones of Chandler, Pelican, and Sweet Charlie, where resistance increased 12-fold. These studies provide evidence that in-vitro screening can be used to evaluate strawberry germplasm for anthracnose resistance and that somaclonal variation is influenced by strawberry genotype.

\section{INHERITANCE OF RESISTANCE TO ANTHRACNOSE}

Gupton and Smith (1991) determined that the estimates of dominance genetic variance were six to 10 times higher than those for additive genetic variance. The frequency distribution of disease severity ratings was bimodal suggesting major gene action. Narrowsense heritability estimates of 0.37 and 0.26 were probably sufficient to produce gains from recurrent selection, while gains from selection of clonal value should be possible because of the high $(0.87$ and 0.85$)$ broadsense heritability estimates. Giménez and Ballington (2002) also found that nonadditive effects were more important than additive effects in the inheritance of resistance on runners. The epistatic nature of anthracnose resistance on runners appears to be supported by results of crosses between susceptible parents that result in up to $20 \%$ resistant seedlings (Ballington et al., 2002). Giménez and Ballington (2002) found that the frequency distribution of lesion lengths within progenies suggests that resistance to $C$. $a c u$ tatum on runners is quantitative. Results of Garcés et al. (2002) also support the theory that inheritance of resistance to anthracnose is quantitative in nature.

Increased losses due to anthracnose fruit and crown rots may be related to the shift from matted-row culture to the annual plasticulture production system in the United States. Breeding for genetic resistance to anthracnose and development of resistant cultivars are primary means for reducing economic loses due to this disease. This is environmentally sound because it results in reduced use of fungicides.

\section{CONCLUSIONS}

As our knowledge of the anthracnose pathogens and the epidemiology of anthracnose diseases has increased, so has our ability to control these diseases. Changes in cultural practices have resulted in reduced levels of disease. At the same time, development of more effective fungicides and their registration for use on strawberries have greatly reduced losses due to both anthracnose crown rot and fruit rot. Anthracnose-resistant cultivars also have reduced economic losses due to these diseases. Even so, growers may sustain severe losses when environmental factors are highly favorable for anthracnose development.

\section{Literature Cited}

Ballington, J.R., J.L. Shuman, B.J. Smith, and S.C. Hokanson. 2002. Breeding strawberries (Fragaria $\times$ ananassa) for resistance to anthracnose caused by Colletotrichum acutatum. Acta Hort. 567:89-92.

Bernstein, B., E.I. Zehr, R.A. Dean, and E. Shabi. 1995. Characteristics of Colletotrichum from peach, apple, pecan, and other hosts. Plant Dis. 79:478-482.

Brooks, A.N. 1931. Anthracnose of strawberry caused by Colletotrichum fragariae, $\mathrm{n}$. $\mathrm{sp}$. Phytopathology 21:739-744.

Curry, K.J., M. Abril, J.B. Avant, and B.J. Smith 2002. Strawberry anthracnose: Histopathology of Colletotrichum acutatum and C. fragariae. Phytopathology 92:1055-1063.

Denoyes-Rothan, B., G. Guerin, C. Delye, B. Smith, D. Minz, M. Maymon, and S. Freeman. 2002. Genetic diversity and pathogenic variability among isolates of Colletotrichum species from strawberry. Phytopathology 93:219-228.

Galletta, G.J., J.L. Maas, C.E. Finn, B.J. Smith, and C.L. Gupton. 1997. The United States Department of Agriculture strawberry breeding program. Fruit Varieties J. 51:204-210.

Galletta, G.J., B.J. Smith, and C.L. Gupton. 1993 Strawberry parent clones US70, US159. US292, and US438 resistant to anthracnose crown rot. HortScience 28:1055-1056.

Garcés, S., F. Hammerschalg, J.L. Maas, M. KochDean, and B. Smith. 2002. Increased resistance to Colletotrichum acutatum is exhibited by leaf explant regenerants derived from several strawberry cultivars, p. 54-57. In: S.C. Hokanson and A.R. Jamieson (eds.). Strawberry Research to 2001. Proc. 5th North American Strawberry Conf., Toronto. ASHS Press, Alexandria, VA.

Giménez, G. and J.R. Ballington. 2002. Inheritance of resistance to Colletotrichum acutatum Simmonds on runners of garden strawberry and its backcrosses. HortScience 37:686-690.

Gupton, C.L. 2000. Use of herbicides and plant growth regulators to suppress Italian ryegrass growth. HortTechnology 10:773-776.

Gupton, C.L. and B.J. Smith. 1991. Inheritance of resistance to Colletotrichum species in strawberry. J. Amer. Soc. Hort. Sci. 116:724-727.

Hammerschlag, F., K. Lewers, S. Ray, and B.J. Smith. 2006. In vitro response of strawberry cultivars and regenerants to Colletotrichum acutatum. Plant Cell Tissue Organ Cult. 84(3):255-261.

Horn, N.L., K.R. Burnside, and R.B. Carver. 1972. Control of the crown rot phase of strawberry anthracnose through sanitation, breeding for resistance, and benomyl. Plant Dis. Rep. $56: 515-519$

Howard, C.M. 1971. Control of strawberry anthracnose with benomyl. Plant Dis. Rep. 55:139-141.

Howard, C.M. 1983. Black leaf spot phase of strawberry anthracnose caused by Colletotrichum gloeosporioides $(=C$. fragariae) . Plant Dis. 67:1144-1146.

Howard, C.M., J.L. Maas, C.K. Chandler, and E.E. Albregts. 1992. Anthracnose of strawberry caused by the Colletotrichum complex in Florida. Plant Dis. 76:976-981.

King, W.T., L.V. Madden, M.A. Ellis, and L.L. Wilson. 1997. Effects of temperature on sporulation and latent period of Colletotrichum spp. infecting strawberry fruit. Plant Dis. 81 : $77-84$.
LaMondia, J.A. 1993. In vitro evaluation of fungicides against Colletotrichum acutatum isolates from strawberry. Adv. Strawberry Res. $12: 34-37$.

LaMondia, J.A. 1995. Inhibition with benomyl to growth in vitro of Colletotrichum acutatum and C. fragariae and strawberry fruit infection by benomyl-resistant isolates of Colletotrichum acutatum. Adv. Strawberry Res. 14: 25-30.

Leandro, L.F.S., M.L. Gleason, F.W. Nutter, Jr., S.N. Wegulo, and P.M. Dixon. 2001. Germination and sporulation of Colletotrichum acutatum on symptomless strawberry leaves. Phytopathology 91:659-664.

Leandro, L.F.S., M.L. Gleason, F.W. Nutter, Jr., S.N. Wegulo, and P.M. Dixon. 2003a. Influence of temperature and wetness duration on conidia and appressoria of Colletotrichum acutatum on symptomless strawberry leaves. Phytopathology 93:513-520.

Leandro, L.F.S., M.L. Gleason, F.W. Nutter, Jr., S.N. Wegulo, and P.M. Dixon. 2003b. Strawberry plant extracts stimulate secondary conidiation by Colletotrichum acutatum on symptomless leaves. Phytopathology 93:1285-1291.

Maas, J.L. 1984. Anthracnose fruit rot (black spot), p. 57-60. In: J.L. Maas (ed.). Compendium of strawberry diseases. American Phytopathological Society, St. Paul, MN.

Maas, J.L. and M.E. Palm. 1997. Occurrence of anthracnose irregular leafspot, caused by $\mathrm{Col}$ letotrichum acutatum, on strawberry in Maryland. Adv. Strawberry Res. 16:68-70.

Madden, L.V. 1992. Rainfall and the dispersal of fungal spores. Adv. Plant Pathol. 8:39-79.

Madden, L.V. and M.A. Boudreau. 1997. Effect of strawberry density on the spread of anthracnose caused by Colletotrichum acutatum. Phytopathology 87:828-838.

Madden, L.V. and L.L. Wilson. 1997. Effect of rain distribution alteration of splash dispersal of Colletotrichum acutatum. Phytopathology 87:649-655.

McInnes, T.B., L.L. Black, and J.M. Gatti, Jr. 1992a. Disease-free plants for management of strawberry anthracnose crown rot. Plant Dis. 76:260-264.

McInnes, T.B., L.L. Black, and J.M. Gatti, Jr. 1992b. Fungicides for control of strawberry anthracnose crown rot in summer nurseries. Adv. Strawberry Res. 11:12-16.

Norman, D.J. and J.O. Strandberg. 1997. Survival of Colletotrichum acutatum in soil and plant debris of leatherleaf fern. Plant Dis. 81:11771180 .

Ntahimpera, N., L.L. Wilson, M.A. Ellis, and L.V. Madden. 1999. Comparison of rain effects on splash dispersal of three Colletotrichum species. Phytopathology 89:555-563.

Simmonds, J.H. 1965. A study of the species of Colletotrichum causing ripe fruit rots in Queensland. Queensland J. Agr. Anim. Sci. 22:437-459.

Smith, B.J. 1987. Effect of nitrogen, phosphorous, and potassium on the severity of strawberry anthracnose crown rot. Phytopathology 77:1691 (abstr.).

Smith, B.J. 1993. Developmental stage and temperature affect strawberry flower and fruit susceptibility to anthracnose. Phytopathology 83:468 (abstr.).

Smith, B.J. 1989. Effect of nitrogen source and level on severity of strawberry anthracnose crown rot. Phytopathology 79:376 (abstr.).

Smith, B.J. 1998a. Anthracnose crown rot, p. 4648. In: J.L. Maas (ed.). Compendium of 
strawberry diseases. 2nd ed. American Phytopathological Society, St. Paul, MN.

Smith, B.J. 1998b. Anthracnose fruit rot (black spot), p. 31-33. In: J.L. Maas (ed.). Compendium of strawberry diseases. 2nd ed. American Phytopathological Society, St. Paul, MN.

Smith, B.J. 1998c. Anthracnose leaf spot and irregular leaf spot, p. 24-25. In: J.L. Maas (ed.). Compendium of strawberry diseases. 2nd ed. American Phytopathological Society, St. Paul, MN.

Smith, B.J. 2002. Susceptibility of vegetative tissues of fruit and vegetable hosts to infection by various Colletotrichum species. Acta Hort. 567:631-634.

Smith, B.J. and L.L. Black. 1986. First report of Colletotrichum acutatum on strawberry in the United States. Plant Dis. 70:1074.

Smith, B.J. and L.L. Black. 1987. Resistance of strawberry plants to Colletotrichum fragariae affected by environmental conditions. Plant Dis. 71:834-837.

Smith, B.J. and L.L. Black. 1990. Morphological, cultural, and pathogenic variation among $\mathrm{Col}$ - letotrichum species isolated from strawberry. Plant Dis. 74:69-76.

Smith, B.J. and L.L. Black. 1991. Greenhouse efficacy of fungicides for control of anthracnose crown rot of strawberry, p. 221-223. In: A. Dale and J. Lubby (eds.). The strawberry into the 21st century. Timber Press, Portland, OR

Smith, B.J. and L.L. Black. 1992. In vitro activity of fungicides against Colletotrichum fragariae. Acta Hort. 348:509-512.

Smith, B.J. and L.L. Black. 1993. In vitro fungicide studies show the occurrence of benomyl-resistant Colletotrichum spp. from strawberry. Adv. Strawberry Res. 12:42-48.

Smith, B.J., L.L. Black, and G.J. Galletta. 1990. Resistance to Colletotrichum fragariae in strawberry affected by seedling age and inoculation method. Plant Dis. 74:1016-1021.

Smith, B.J. and C.L. Gupton. 1993. Calcium applications before harvest affects the severity of anthracnose fruit rot greenhouse grown strawberries. Acta Hort. 348:477-482.

Smith, B.J., C.L. Gupton, G.J. Galletta, J.L. Maas, J.M. Enns, J.R. Ballington, Jr., R.J. Constantin,
T.J. DiVittorio, and D. Himelrick. 1998. 'Pelican' strawberry. HortScience 33:1082-1084.

Smith, B.J. and J.M. Spiers. 1982. Evaluating techniques for screening strawberry seedlings for resistance to Colletotrichum fragariae. Plant Dis. 66:559-561.

Smith, B.J. and J.M. Spiers. 1986. Influence of mulch and irrigation types on strawberry anthracnose-crown rot. HortScience 21:946 (abstr.).

Sreenivasaprasad, S. and P. Talhinhas. 2005. Genotypic and phenotypic diversity in Colletotrichum acutatum, a cosmopolitan pathogen causing anthracnose on a wide range of hosts. Mol. Plant Pathol. 6:361-378.

Sutton, B.C. 1992. The genus Glomerella and its anamorph Colletotrichum, p. 1-26. In: J.A. Bailey and M.J. Jeger (eds.). Colletotrichum: biology, pathology and control. CAB International, Wallingford, U.K.

Wedge, D.E., B.J. Smith, R.J. Constantin, and J.P. Quebedeaux. 2007. Fungicide management strategies for control of strawberry fruit rot diseases in Louisiana and Mississippi. Crop Prot. 26:1449-1458. 